\title{
The five residential settlements built by HICA
}

\author{
César Machado Moreira ${ }^{1,1}$ \\ ${ }^{1}$ Centro de Estudos Arnaldo Araújo / Universidade Lusíada do Norte , Faculdade de Arquitectura \\ e artes, Porto, Portugal
}

\begin{abstract}
With the exception of some individual buildings, the areas of residential housing constructed by the Cávado Hydroelectric Company (Hidroeléctrica do Cávado, or HICA) were not included in the debate on housing that was taking place at the time of their building, and later on were not considered worthy of any special attention. Despite their creation having been of fundamental importance to the construction and maintenance of the infrastructure of the Cávado hydroelectric scheme, from an architectural point of view these settlements only became wellknown for being the location of four buildings that were designed by the architect Januário Godinho: three Pousadas and a restaurant.

The housing settlements were the result of a merging of the expectations of management, the bureaucratic systems of the technical services department and the needs dictated by the circumstances that were encountered as the work progressed. In other words, the hydroelectric development of the Cávado was the reason for the implantation in that location of an urban structure that had been designed and produced in a technical services department based in Porto.
\end{abstract}

\section{The first settlement}

When creating the initial concept for the Cávado hydroelectric scheme, the French specialist André Coyne had warned of the need to build housing for the future workers of the dam. It was only when the work was already well advanced that the HICA engineers finally understood the vital necessity of creating housing close to the power station buildings. The first housing settlement that was brought into being, at Venda Nova (Sidróz), had repercussions on the planning of the hydroelectric schemes that were built in Portugal in the 1950s and 1960s, both on the subsequent reaches of the Cávado river as well as on the schemes developed for the Zêzere river and ${ }^{2}$, later on, on the stretch of the Douro river that borders with Spain. The prior experience of André Coyne would associate the proposals for these housing settlements to the dams with which he was involved during that decade, which were mostly located in remote regions

\footnotetext{
${ }^{1}$ Corresponding author: cmoreiraarq@gmail.com

${ }^{2}$ André Coyne worked simultaneously with HICA and with HEZ (the Zêzere Hydroelectric Company) on the creation of the first dams built by these two companies.
} 
of the French $\mathrm{Alps}^{3}$. Nevertheless, there is nothing to suggest that any attention was paid by the HICA technicians to previous residential projects on the large dams that were the technical reference for the construction of the Portuguese hydroelectric schemes ${ }^{4}$.

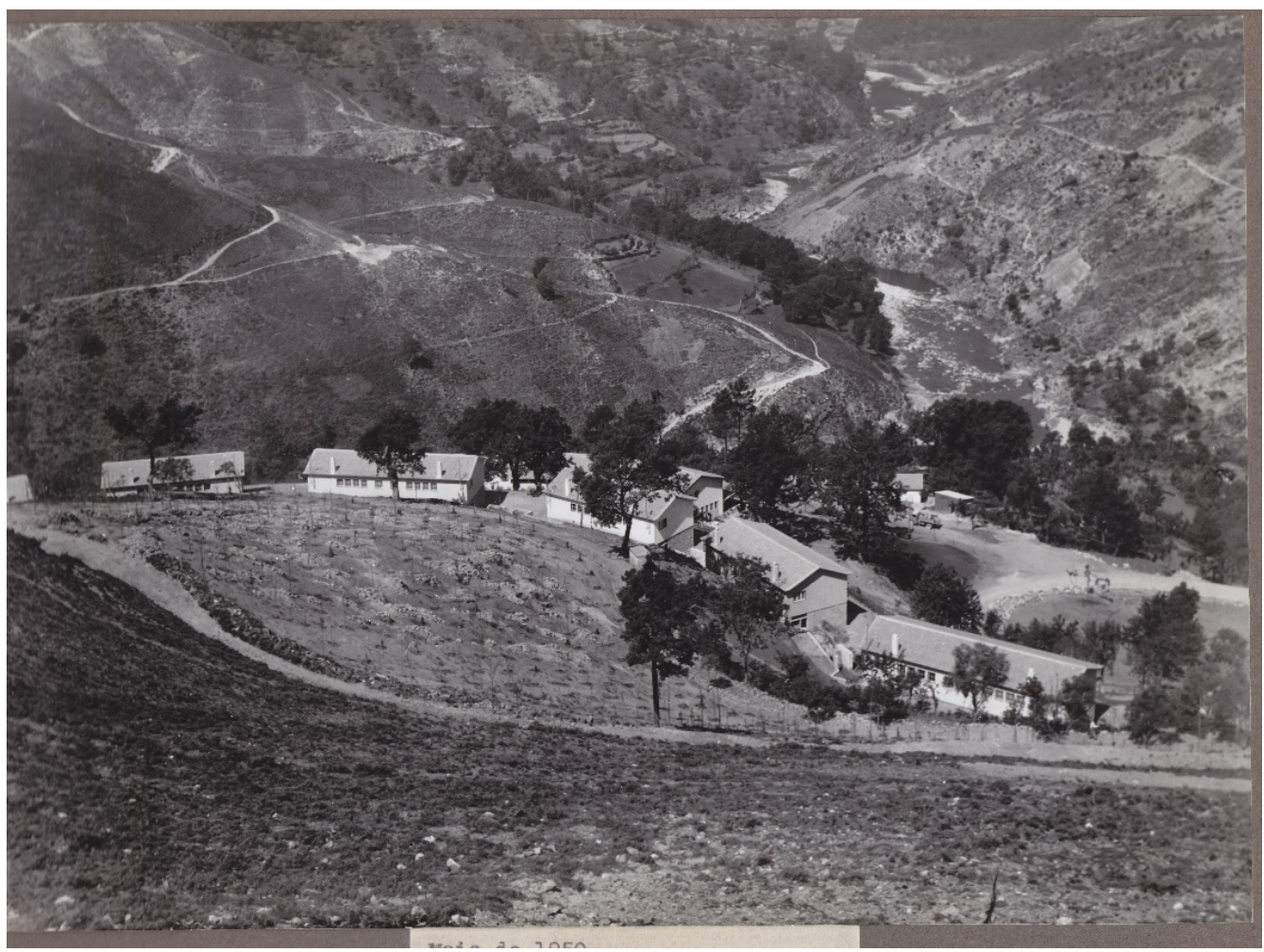

Fig. 1. Settlement of Venda Nova, 7 May 1950.

Photo: Casa Alvão [photo agency]. Source: ATEDP (Arquivo Tecnico da EDP).

The need to house the technical staff of the company, who worked on-site during the preparation and construction of the dam, together with difficulties caused by the lack of availability of housing suitable for its senior managers, caused HICA to take the decision to move forward with the construction of the first residential housing settlement. The objective for the first phase was to find a solution to the problem of providing housing for the company's own technicians, which once the work was finished would then serve as residences for the workers at the power station and their respective

\footnotetext{
${ }^{3}$ In 1935, André Coyne was director of the department of large dam engineering in France, and between 1945 and 1953 was president of the International Commission on Large Dams, ICOLD. In 1947, he founded engineering company Coyne et Bellier with Jean Bellier, working on projects which included the dams of Dordogne (1928), Maréges (1935), Tignes (1952), Malpasset (1954), Migoelou (1958) and Roselend (1960).

${ }^{4}$ The second half of the $20^{\text {th }}$ century saw many examples of residential settlements built next to dams in Spain, France, Italy, Switzerland and the USA, for the purpose of housing the workers at the power stations. Although these settlements were never cited as references, by means of the journeys undertaken and the information available to the HICA engineers at the time we can assume that they would have been aware of the existence of residential settlements of this type.
} 
families. In accordance with the social model practised by the large manufacturing ${ }^{5}$ and mining industries of the time [2], HICA drew up a practical plan which contained not only housing but also supporting infrastructure.

HICA engineers Correia de Araújo and Sarmento Beires were responsible for the creation of the foundation programme for the first housing settlement to serve the workers of the Venda Nova power station. The programme was conceived for 36 workers, the number it was thought necessary to run the hydroelectric power station. It was these same engineers who carried out the "selection of the site, after a painstaking examination of the terrain around the power station, given that closeness to the station was considered to be of fundamental importance" ${ }^{\prime 6}$. With the programme and the location now chosen, development of the projects was entrusted to Januário Godinho, after he had completed the design of the new village at Venda Nova.

The experience gained on the first housing complex did not enable HICA, when working on the next reaches of the dam, to avoid a constant stream of unforeseen situations. In Salamonde, construction of the settlement was brought forward to house the technical staff during the building work, but the combination of both permanent and temporary constructions being built on a single site, which demanded the integration of housing and supporting buildings to serve groups of differing social status, led to a programme that was much larger and more complex than originally planned.

In the following reaches - those of Caniçada and Paradela - HICA had not intended to build new settlements, and the reasons for this were clear. In Paradela, with the expectation that the reservoir water would go to the turbine at the Venda Nova power station, there was no need for workers to be located next to the dam. At Caniçada, the proximity of relatively well-developed villages suggested the possibility of using the infrastructure that was already there, with just a few houses needing to be built. The settlement at Caniçada was reduced to a small collection of 18 houses, scattered along National Road 301, with the hostel being replaced by two buildings (a dormitory and a restaurant) which were initially supposed to be temporary. Januário Godinho was once again called on to design the permanent buildings, taking on the houses, the dormitory and the restaurant, as well as extending his sphere of action to include selection of the location of the temporary pavilions.

In the case of Paradela, no definitive settlement yet existed, but the unusual characteristics of the construction of the dam meant that a substantial number of workers were needed on site for the duration of the project. Difficult access routes and the lack of any villages close by the site led to the creation of a series of lodgings and temporary facilities, built on a large scale. Due to the type of dam that was to be built - a rock-fill dam - it is understood from the existing documentation that the technicians involved in its design and construction were clearly concerned about the preceding reaches. Initial plans for the establishment of the construction sites suggested a small area containing just a few prefabricated pavilions, probably chosen based on the smaller amount of labour needed for this type of building. It was only as work on the

\footnotetext{
${ }^{5}$ During the $19^{\text {th }}$ century and the first half of the $20^{\text {th }}$ century, there were in Portugal several very large companies in the more traditional industries of ceramics, flour milling, textiles, paper and canning. It was sometimes felt in these areas of large-scale manufacturing that housing for the workers of their industries needed to be directly promoted. In the majority of cases, the housing that was built was not attributed any special historical value, however it was very well organized from a social perspective. See also on this subject: [1].

${ }^{6}$ Memória Descritiva e Justificativa do Aglomerado Habitacional da Central de Vila Nova [Descriptive Report and Justification of the Housing Cluster of the Vila Nova Central] (1948). 20 January: 2. Porto, ATEDP, PRT-1948-00001.
} 
dam developed that housing for the workers began to assume greater importance. This did not occur in an organized fashion however, but rather as a response to immediate needs, which were on the whole unforeseen and unplanned. This lack of planning is visible in the manner in which the different buildings were located on the two hillsides, the ruins of which can still be seen today. The buildings, the architectonic design of which were intended to be neutral and irrelevant, are located at random along secondary roads without any attempt having been made to create a cohesive group. From amongst this set of dwellings, the Pousada building stands out, isolated at the highest point and with formal characteristics that are distinct from the other constructions, which were intended to be demolished when the project was finished.

The stretch of waterway of Alto Rabagão, Pisões was the location for the last housing settlement built by HICA and had specific characteristics which were very different to those on previous reaches of the scheme. The conditions which led to the construction of the dam, as well as the size of the project and the funding obtained, permitted the company to create a larger housing settlement, endowed with an infrastructure that was not given to the first residential areas, such as a hospital, market and shopping area. The size and extent of the work on the dam brought complications to the organization of the construction site and its respective accommodation areas, and, as at Venda Nova, housing for the construction workers was treated in a different manner to that for the workers at the power station. The participation of Januário Godinho on this section of the scheme was less than it was on the first reaches, as the designs for the housing settlements were made by the architects who were already working for HICA, in particular by architects Costa Pereira and João Castelo Branco. Januário Godinho did however work on some plans for Alto Rabagão ${ }^{7}$, although of these, the only design that came to be built was the one for the Pousada.

Between 1947, with the initial recommendations of André Coyne, and 1960, when the housing settlement at Pisões was completed, the policy of HICA relative to housing settlements for the workers was both erratic and unstable. The only understanding to be got from this situation is that there was no clear policy of action in existence that was able to guide and organize the use of the land in the Cávado valley in accordance with a clear and identifiable vision for the terrain.

\section{The fiction of the "Garden City" as a model of reference}

Despite the diverse contexts in which the housing settlements were being constructed, the main criteria used in their planning were similar in all cases. In Venda Nova, the engineers decided that the location of the housing settlements should always be as close as possible to the power stations to allow the workers to walk between the workplace (the power station) and their accommodation (the housing settlement). The sites needed to have good exposure to the sun and even terrain to enable construction costs to be kept down. Each site that was chosen for a housing settlement was surrounded by a perimeter strip of private land for the exclusive use of company employees, which created an isolated community that consisted solely of workers and

\footnotetext{
${ }^{7}$ In the list of works carried out by the studio, handwritten by Januário Godinho, there are references to the plans for the Pousada, the housing settlement and the power station for Alto Rabagão, but in front of the last two, the architect wrote in brackets: shelved. Relative to the scheme at Alto Rabagão, with the exception of the Pousada no designs of other plans by Januário Godinho have been found in the archives that were consulted. It is assumed that for the final reach of the hydroelectric scheme, the architect did not work on any plans apart from those for the Pousada.
} 
their families. This model varied, particularly in Caniçada, where the area of residential housing was spread along the national road.

Based on the instructions provided by HICA technicians, Januário Godinho chose to plan the layouts of Venda Nova, Salamonde and Caniçada as a group of houses, either semi or fully detached, arranged on the site with green spaces around them, in clear dialogue with the social buildings which were set apart at positions of relevance on the site. These organizational principles reflected the experience he had gained in his work in the area of town planning. Between 1942 and 1947, Godinho created town plans for several municipalities at the request of the department for national buildings and monuments (Direcção-Geral dos Edifícios e Monumentos Nacionais - DGEMN) ${ }^{8}$. The experience gained led him to apply some of the strategies that he had learnt to the conception and design of the small housing settlements ${ }^{9}$ that he created for HICA [3].

To what extent can Howard's utopian model, brought to Portugal by means of a French interpretation of the work of English architects ${ }^{10}$, be seen in the small workers' villages of the Cávado? What seems to have happened is that these ideas were simply expressed through the creation of individual houses, surrounded by abundant vegetation, with facilities and social areas set apart in their own individualized spaces. At Cávado, the issue at stake was not the complex problem of an urban development plan for a Portuguese town or city, nor was it the construction of a new Utopia, but simply a response to a need for housing that had not even been envisaged at the outset.

\section{The composition of a new landscape}

The technicians of HICA, although in charge of the programme, did not dictate the criteria for the composition or layout of the workers' villages. Faced with a location in which human intervention had been non-existent or negligible and was not likely to occur apart from in relation to energy production at the power stations, the architect therefore had a large amount of autonomy with regards to the conception and planning of the settlements. His plans, created together with the staff of the special engineering projects department at HICA (the SEP), were presented by the department's chief engineer to the Board of Directors, which, after approval, were sent to JAE and MOP for ratification. Despite the fact that the sites on which the residential areas were

\footnotetext{
${ }^{8}$ The proximity of Godinho to architects Rogério de Azevedo and Baltazar de Castro, both of whom had links with DGEMN, would certainly have facilitated the choice of Godinho for inclusion in this select group of architects and town planners. Rogério de Azevedo was architect for the Porto section of the department for national buildings and monuments, and Baltazar de Castro worked at DGEMN between 1929 and 1947, holding a variety of positions, culminating in his taking up the post of head of the department of monuments, shortly before leaving DGEMN to become chief inspector of public works.

${ }^{9}$ Decree Law no. 24802 of 21 December 1934 provided municipalities with full powers relative to the transformation of their territory through the means of Planos Gerais de Urbanização [General urban development plans]. The municipalities were obliged to carry out topographical surveys of their land, as well as of all locations consisting of more than 2,500 inhabitants. In 1938, a commission for the inspection of urban topographical surveys was created, as well as a department of urban improvement, both of which were linked to DGEMN. For more on this matter see the work of Lôbo [3] and the article by [4].

${ }^{10}$ The presence of Barry Parker in Porto, although a regular occurrence, did not make any notable impact on the local architectural community. See [5].
} 
constructed were governed by the building regulations of their respective municipalities, there is no record that the local town councils were consulted on the nature of these plans ${ }^{11}$.

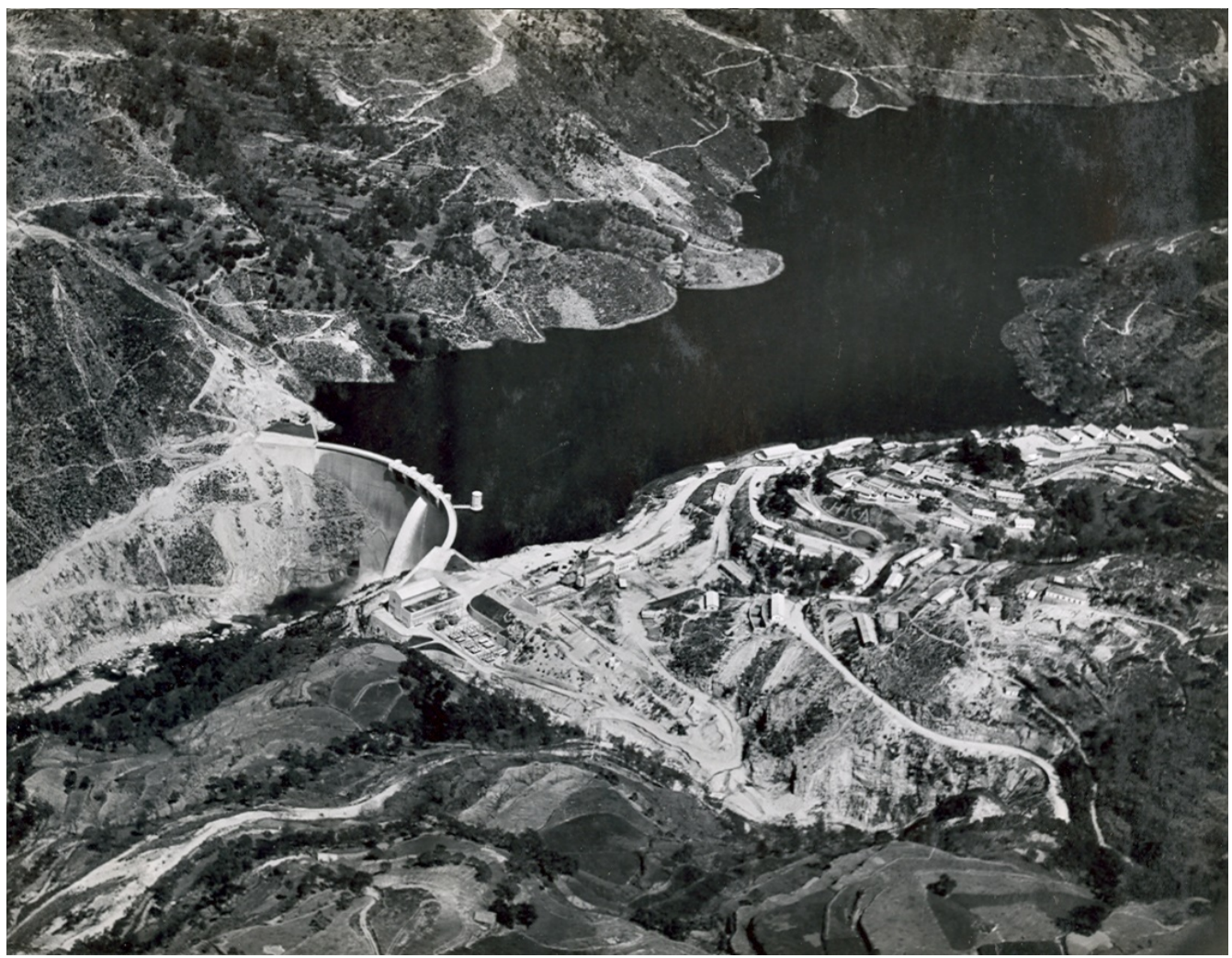

Fig. 2. Dam construction, Salamonde, 1955. Photo: Casa Alvão; Source: ATEDP.

The fact that the housing settlements were located on sites that had experienced little or no human intervention permitted Januário Godinho to create plans for the villages that were enclosed and completely self-contained, and included designs for the different types of houses, collective spaces and religious, educational and social buildings. The attention paid to the topography, the orientation of the buildings, and to the planting, permitted the establishment of a physical relationship with the surroundings which differentiated the settlements from other residential areas in the region. From the construction of the very first village, the plans presented a set of constant values which can be summarized in the following points:

I) The use of the topography, with the roads curving back on themselves to deal with the slopes of the hillsides;

${ }^{11}$ The municipality of Montalegre was only consulted in relation to the creation of the plan for the new village at Venda Nova, which was located on land that did not belong to HICA. In that particular case, the decision relative to location was made by the municipality. Acta $n^{\circ} 117(1947)$. [Minutes of a board of directors' meeting]. 26 November: 1. Source: AHME - Arquivo Histórico do Museu de Electricidade, ARCAHICA - Arquivo da Central de Caniçada, Hidroeléctrica do Cávado. 
II) The interruption to the perspective: the layouts of the settlements are hidden by the roads as they curve in on themselves, causing the settlements to appear as if by surprise;

III) The height of the houses was always the same, never exceeding two floors;

IV) Social hierarchy was explicit in the relative positions of the buildings and in their differing designs;

V) There are no pavements, the road is the collective space; access to the houses is made by granite pathways passing through areas of green space which do not belong to any particular house.

In Venda Nova, the lack of pavements or external walls dividing the houses transformed the street into a collective space of cohabitation amongst the residents. The narrow streets and the lack of parking indicate the relative status of the car, and it can be noted that the house of the chief engineer was the only one of the village to have been provided with a garage. Pedestrian pathways are given a high status in all the settlements, as are occasional or small-scale interventions that help to domesticate the paths. The houses, built at different elevations, are connected by narrow paths and steps which blend in with the new planting scheme. The streets and the retaining walls, also in granite, add greatly to the creation of the new image of the settlement. The way in which the planned layouts of the green areas transform the site also help to underline its irregularity and to create the distinctive image of the settlements.

Independent of any connection to models that are rationalist to a greater or lesser extent, from the possible proximity to the cities "of the rural Anglo-Saxon tradition and the ideas of Camillo Sitte on the irregularity of the organic city" [3], the curvilinear forms of the HICA villages embody an extreme sensitivity to the adaptation of constructions to their terrain, and of using the topography to create a group of buildings that appears natural; without any explicit rationale.

If there is a distinctive feature of these settlements, it is the contrast between the private life that takes place inside the dwellings and the public nature of the streets. Between these two realities, it is the public buildings that guide the composition of the settlement as a whole. By reconfiguring the gardens, green spaces and pedestrian footpaths on the terrain, the plans for the settlements firmly renounce any possible historical continuity between the original nature of the terrain and the new occupation of the space. A new landscape has been configured, one in which the Pousadas, restaurants and other buildings of public use add to the perception of the settlement as a whole and serve as a reference for the composition and layout of the site.

\section{A theory of landscape in the HICA settlements}

The HICA housing settlements were conceived in terms of the new landscapes created by the dams that were under construction at that time. The curvature and adaptation to the terrain brings an order to the exterior space which is lost amongst the gaps created by the houses, opening up perspectives the quality of which were improved by the planting plans instigated. We know that no landscape architects participated in the planning of the HICA settlements ${ }^{12}$, the decision relative to location of the site was an administrative one, and the definition of the structure and urban planning was left to the architect. The designs created by Godinho always included green spaces around the

\footnotetext{
${ }^{12}$ The decision on the types of trees to be planted as well as their location was made by the local forester at Vieira do Minho, working together with HICA.
} 
buildings, indicating a strong commitment to a merging of the built space with nature in its landscaped form. The images achieved immediately after construction are very different to those that we see today. The extensive vistas and the view of the entire settlement, visible in the 1950s, have given way to the image, desired by Godinho, of an isolated group of buildings surrounded by dense vegetation.

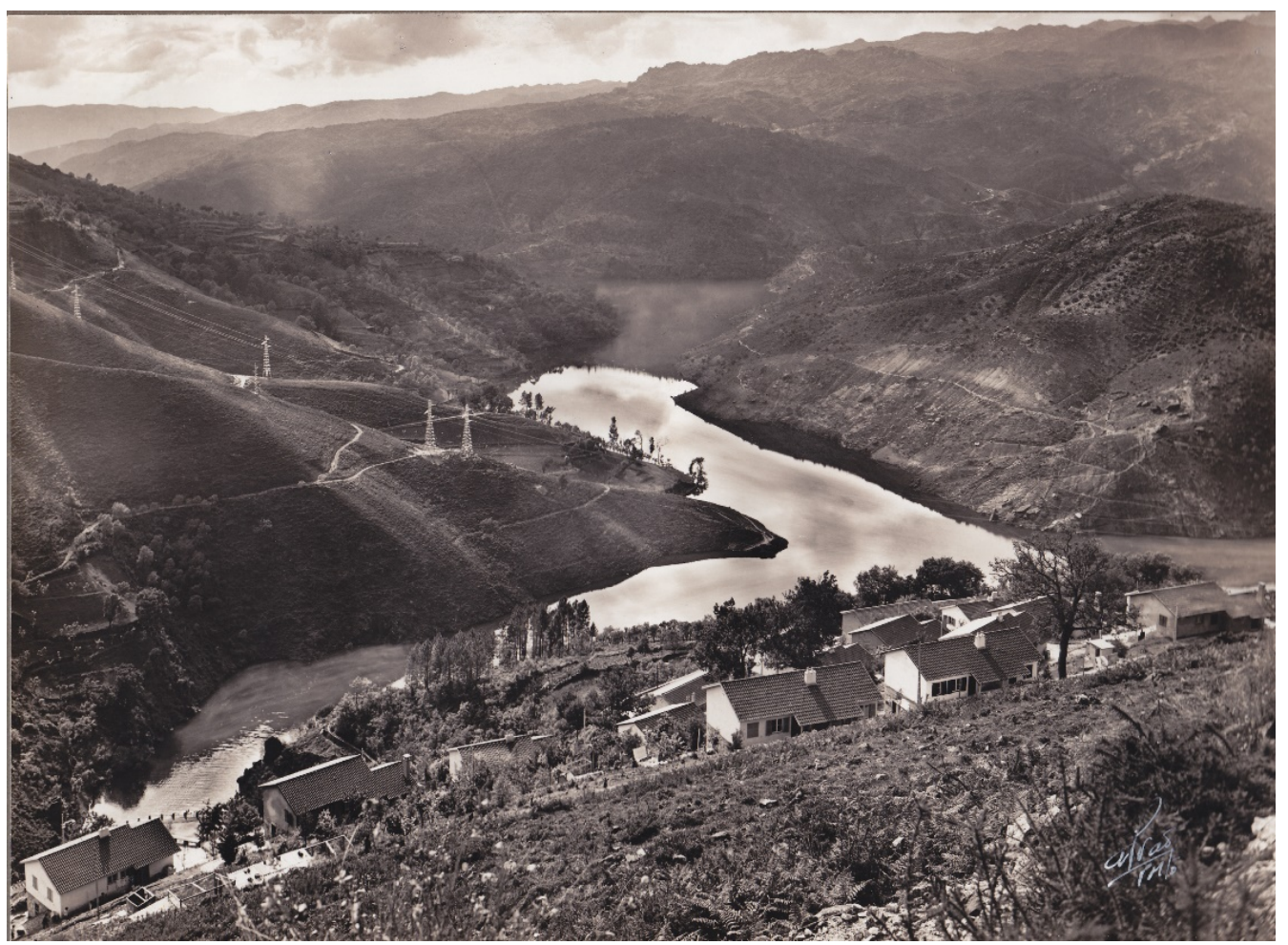

Fig. 3. Settlement of Venda Nova, 1956, Casa Alvão, ATEDP

In the initial diagrams for the plans for Salamonde, the huge swathe of surrounding greenery and the notes pencilled in by Godinho, indicating the directions of the vistas from the Pousada, reveal the search for an image that is controlled by the architect. When construction started, the scanty vegetation that existed at the site was removed, enabling an angle of view that was much greater than the one that can be seen today, which achieves the dense greenery so desired by the architect.

This seeking to achieve an appropriate relationship with nature is one of the characteristics of the architecture of Godinho. The construction of the settlements was conceived from a realistic starting point in which immediate economic necessities had to be taken into consideration, but in which the poetic sensibility of the architect can still be seen in the details and textures of the settlements. The treatment of the exterior spaces was designed as a 'non-designed' space, a natural space, containing the minimum amount of finishes, with small granite walls of clear rural influence placed amongst the trees and plants, which with their simplicity and lack of artifice are always present in plans created by Godinho. The idea of landscape in the construction of the HICA housing settlements can only be understood in terms of their relationships in time as well as space [6]. it is the dynamic of this content that expresses the transformations and tensions in the cultural appreciation of the landscape itself. 
The settlements created by HICA were notable for their social programmes, developed in accordance with hierarchical levels. When the design of the settlements was being developed, no thought at all was given to the relationship between the new inhabitants and the existing populations. Those villages next to the dams which were not submerged during construction of the hydroelectric schemes rarely benefited from any improvements from their proximity to the new infrastructure. The ancestral practices, knowledge and ways of life of the local people had nothing in common with the modern settlements constructed by HICA for its workers.

This dichotomy was also reflected in the architecture. The houses in all the settlements were grouped to conform to the desire of the architect, the topography of the terrain, and conditions relative to orientation and exposure to the sun. The houses in the settlement were integrated into the landscape very often after large-scale movements of earth to enable transformation of the very steep hillsides into terraces, against which the houses would nestle.

The different types of dwellings were designed to present close visual harmony with the settlement as a whole, having little variety and meeting the needs of the specific conditions of their inhabitants. Each settlement contained two or three types of house, consisting of one or two floors, varying mainly in the number of rooms they had and in the relationships between the social areas of the house; individually laid out in the case of houses for managers, and communal areas for the remaining employees. Supporting infrastructures were located strategically in the settlement: The "Centre for happiness at work", the chapel, the market and the Pousada.

In all the settlements "the existence of a set of buildings that exhibited an evident formal and functional analogy as a cohesive group" can be found [7]. The houses designed by Januário Godinho followed rules that defined a model which, with few alterations, was used for all the different inhabitants and housing settlements. The types of houses built at Vila Nova, were, with minor alterations, used at Salamonde and Caniçada; even at Pisões, which was planned by a different architect, the influence and adoption of these same measures is visible.

Receptive to the standardization of the built environment, Januário Godinho worked with the materials available, striving to combine economic constraints with the possibilities of nature.

The buildings that were constructed do not bear any resemblance to the rudimentary buildings that existed in the surrounding villages. Stone houses, in granite or schist depending on the location, and thatched roofs, which were common in that area, are distant predecessors of the systems of construction adopted for the buildings of the settlements for reasons of cost and standardized production. The pillars and beams in concrete, voided slabs, walls in brick or granite when there was a need to raise the basements of the buildings, and the roofing in tile covering a wooden structure. The technologies and construction methods available for the power stations and dams were, intentionally, used to a small degree in the construction of the settlements.

The architecture of the HICA settlements cannot simply be classified as "a question that relates to the use of the more readily available local materials, or of copying any simple method of construction used, due to the lack of anything better, by our predecessors of a generation or two gone by" [8].

The housing settlements of Venda Nova, Salamonde and Caniçada, which were designed by Godinho, display "his sense of place and access to a healthy empiricism that is visible in the choice of materials, the inflections and curvatures of the areas, and in the relationship of empty space to the landscape" [9]. 
Where there once was wasteland, hills and mountain ranges, came houses, buildings and streets in which new communities of outside workers were housed.

It was in this context that Januário Godinho worked. His architecture did not seek to mimic the existing constructions; everything he proposed was new. There was no intention of blending the new settlements in with other villages. Locations were chosen for reasons of practicality and functionality, a policy which was applied to the different houses and facilities that made up the settlements. The architectural qualities that Godinho incorporated into the HICA housing settlements can be seen in the way in which the images of this architecture, implanted onto the existing landscape without ever being, or desiring to be, considered 'rural', have become etched onto the collective imagination.

\section{Acknowledgements}

MODSCAPES is a collaborative research project funded under the HERA - Humanities in the European Research Area ${ }^{\text {rd }}$ Joint Reseach Programme dedicated to "Uses of the Past" (20162019). This project has received funding from the European Union's Horizon 2020 research and innovation programme under grant agreement $n^{\circ} 649307$.

\section{Short resume}

César Machado Moreira. Architect (ULP, 1998). PhD candidate (FA/University of Porto) with a FCT research grant: SFRH/BD/72332/2010. He holds two Architecture Masters (ULF, 2009; E.T.S. Barcelona, 2000). He teaches studio design at Universidade Lusíada since 2001 and is affiliated researcher at CEAA - Centro de Estudos Arnaldo Araújo. He was researcher of FCT R\&D project "Photography, Modern Architecture and 'Escola do Porto': Interpretations on Teófilo Rego Archive" (2014/2015) and currently, he is a member of MODSCAPES team.

\section{References}

1. CUSTÓDIO, J., A 2005. "A industria portuguesa na época do Movimento Moderno (1925-1965)" [The Portuguese industry at the time of the Modern Movement (19251965)], in C. Garcia Braña, S. Landrove, A. Tostões (eds.), A Arquitectura da indústria, 1925-1965, Registo Docomomo Ibérico, Barcelona, Fundação Docomomo Iberico - Actar: 14-35.

2. MATOS, J.X. et al., 2002. "Património mineiro português: estado actual da herança cultural de um País mineiro" [Portuguese mining heritage: current state of the cultural heritage of a mining country], in J.M. Brandão (ed.), Actas do Congresso Internacional Sobre Património Geológico e Mineiro (Beja: 4-7 October 2001) Lisbon, Museu do Istituto Geológico e Mineiro: 539-554.

3. LÔBO, M.S. 1995. Planos de Urbanização, A época de Duarte Pacheco, [Plans of Urbanization, The time of Duarte Pacheco], Porto, FAUP Publicações, 1995.

4. GONÇALVES, F. 1986. "A propósito dos planos de urbanização do estado novo: projectos urbanísticos ou regulamentos policiais?", Sociedade e território: revista de estudos urbanos e regionais, vol. 2, $\mathrm{n}^{\circ}$ 4: 92-115.

5. TAVARES, A. 2011. "A Avenida da evolução das cidades nas Nações Aliadas: notas em torno de Marques da Silva e Barry Parker", in R.J. Garcia Ramos (ed.), Leituras de Marques da Silva, Reexaminar a modernidade no início do século XXI: arquitectura, cidade, história, sociedade, ciência, cultura [Readings of Marques da 
Silva: A re-examination of modernism at the beginning of the $21^{\text {st }}$ century: architecture, city, history, society science, culture], Porto, Fundação Instituto Arquitecto José Marques da Silva: 133-145.

6. ANDRESEN, M.T. 1992. Para a critica da paisagem [For the criticism of landscape], PhD dissertation, Universidade de Aveiro.

7. ARGAN, G.C. (1963) 1996. "On the typology of architecture", in K. Nesbitt (ed.), Theorizing a New Agenda for Architecture: An Anthology of Architectural Theory 1965-1995, New York, Princeton Architectural Press: 240-247.

8. MUMFORD, L. 1941. The South in Architecture, New York, Harcout Brace. Retrieved from: https://archive.org/details/southinarchitect009074mbp [available on 16 January 2019].

9. PORTAS, N. 1987. "Januário Godinho - 1910", in Catálogo da exposição, Arquitectura, Pintura, Escultura, Desenho, integrada nas comemorações do $75^{\circ}$ aniversário da UP, [Catalog of the exhibition, Architecture, Painting, Sculpture, Drawing, integrated in the commemorations of the $75^{\text {th }}$ anniversary of UP], Porto, Universidade do Porto, 1987. 